\title{
The Economic Impact Of Water Quality Standards: A Case Study Of The Steel Industry In Youngstown-Warren, Ohio
}

\author{
LAWRENCE H. REVZAN*
}

\begin{abstract}
This paper assesses the economic impact of implementing water quality standards for the Mahoning River Valley on the Youngstown-Warren, Ohio, metropolitan area. The river has been assigned "stream quality criteria" that will prove very costly for the steel industry, the major source of pollution, to achieve. In addition, the use of economic base analysis indicates that the strict enforcement of the water quality standards will have a significant negative economic and fiscal impact on the entire region.
\end{abstract}

\section{INTRODUCTION}

The purpose of this paper is to assess the economic impact of implementing water quality standards for the Mahoning River (and its tributaries) on the Youngstown-Warren, Ohio, metropolitan area. The primary users of the Mahoning River are several large steel mills located along its banks and the waste water systems of some 13 municipalities in the area.

The paper focuses on the steel industry and, after determining how the steel firms intend to react to the imposition of the standards, traces the consequences of these intended actions on the economy of the Youngstown-Warren, Ohio Standard Metropolitan Statistical Area (Y-W SMSA-comprised of Mahoning and Trumbull counties) and the fiscal positions (revenue and expeditures) of the local units of government in the area.

\section{Water Quality Standards}

The Ohio EPA (formerly the Ohio Water Pollution Control Board, Department of Health) has implemented a pollution control program for the Mahoning River and its tributaries. The program has three important components. ${ }^{1}$

(1) The entire river area has been assigned stream quality criteria, which consist of "minimum conditions applicable to all waters at all places and at all times," and specific criteria applicable to the uses to which water at

*The author is a Manager in Management Consulting Services of Ernst \& Ernst. This paper summarizes a study performed for the Western Reserve Economic Development Agency, Inc. (WREDA) in Youngstown-Warren, Ohio (William A. Sullivan, Jr., Executive Vice President). The views expressed in this paper do not necessarily represent those of the WREDA. 
various intervals (zones) along the river is put (e.g., public water supply, industrial water supply, recreation).

(2) Specific effluent standards have been established which all polluters must meet in order to attain the desired river quality. These standards have been translated into specific requirements by industry, firm, and plant. The "critical constituents" of concern to the steel industry are thermal pollution, dissolved iron, ammonia, cyanide, phenols, zinc, suspended solids, and oil.

(3) A time schedule has been established within which specific elements of an overall pollution control program must be completed. This again is identified by industry, firm, and plant.

\section{Economy of the Region}

The economy of the Y-W SMSA depends heavily on the steel and automotive industries (including assembly and electrical components). ${ }^{2}$ The larger trading area (which includes Mercer and Lawrence counties, Pennsylvania) also contains steel mills and related establishments producing electrical and nonelectrical machinery (transformers, metalworking machinery, conveyors) which use steel to varying degrees in their production processes. The steel mills in the Mahoning Valley are generally old (built before World War II) and of the open-hearth type. Open-hearth furnaces are less efficient than the newer basic oxygen furnaces (BOF) and electrical furnaces in the production of steel and emit greater concentrations of pollutants (per thousand tons of steel produced) than the newer, more efficient mills. In addition, major markets for steel have been developed in the Southwest and West, where newer, more efficient, and "cleaner" mills have been built by the industry. Finally, imports of high quality, relatively inexpensive steel from Japan and Western Europe have penetrated the U.S. market (both raw steel and durable goods containing steel such as automobiles) and eroded the existing market positions of U.S. steel producers. ${ }^{3}$

Thus, the Mahoning Valley now has several large, "marginal" steel mills in an industry whose long-term future (to 1980), while bright, is still subject to strong cyclical patterns which have traditionally created cash flow and capital financing problems for the industry. In addition, the Mahoning River has been polluted for years (its water temperature averages 90 degrees ( $F$ ) along the study area during the summer months), and it will be very costly to clean up within the acceptable limits established by the Ohio EPA.

Other important observations regarding the economy of the study area can be summarized as follows:

1. The economy of the Y-W SMSA remains highly dependent on basic steel for employment and earnings, although to a far lesser degree than a decade ago. Basic steel, which accounted directly for 21.1 percent of total non-agricultural employment and 46.2 percent of manufacturing employment in 1961 (32,900 jobs), was still responsible for a significant number of jobs in 1972 (29,700). This figure, however, represents only 14.3 percent of total non-agricultural employment and 31.9 percent of manufacturing employment. ${ }^{4}$ Gains in other manufacturing 
sectors, plus significant gains in the retail trade, services, and government sectors, have led to a more diversified economy in the Y-W SMSA at present than ever before.

2. While the economy has grown over the past 12 years (a total of 45,000 new jobs represents an increase of 29 percent between 1961 and 1972; 16,000 new manufacturing jobs constitute an increase of 22 percent in that sector), this growth has been subject to three cyclical downturns.

a. The 1961-63 recession, during which total employment declined (only to recover sharply during the 1964-66 period).

b. A slowdown during 1966-67, during which time employment remained steady, with a surge in transportation equipment manufacturing employment offsetting a decline in primary metals manufacturing employment (1966 was the peak year for employment in basic iron and steel production during the 1961-72 period); again, the economy recovered sharply during 1967-69.

c. The major recession of 1969- mid-1971, which the Y-W SMSA survived very well (even though unemployment exceeded 6 percent in 1970), recovering quickly in 1971 on the heels of a major surge in employment in automobile manufacturing at the General Motors' Lordstown plant.

3. While the 1970's should be a period of overall expansion in the U.S. economy, the economy is still subject to the types of cycles which affected the $Y-W$ SMSA adversely during periods of the 1960's. The legislative mandate of the Federal and Ohio State Environmental Protection Agencies and the problems faced by automobile and steel manufacturers-the core of the Y-W economy-in meeting EPA standards make this a period of great promise, but even greater uncertainty, in the Mahoning Valley.

\section{STUDY METHODOLOGY}

The general methodology employed in the study is called "Economic Base Analysis." ${ }^{5}$ The heart of this type of study is the construction of a model of the economy in a region, including the linkages among all producers of goods within the region's boundaries (as suppliers to and purchasers from each other). In addition, the analysis determines the degree to which a region "imports" its raw materials, intermediate products, and finished products from outside its boundaries and "exports" products (raw materials, intermediate, finished) to purchasers located outside its boundaries. This basic information is utilized in a general Keynesian-type model to ascertain the full impact of changing economic conditions (either internally or externally induced) on levels of employment and income within the region.

The two-county area (Mahoning and Trumbull counties), defined as the "region" in this study, represents a single labor market and trade area. Most residents of the two counties (about 86 percent in 1970) work within the twocounty boundary and purchase goods and services from establishments located within the two-county area. This is particularly true of steel mill workers, who 
are generally older and less mobile than workers in the automobile assembly plant. However, the definition of "region" is also broadened in certain cases to include Mercer and Lawrence counties, Pennsylvania (included in the trade area by the U.S. Department of Commerce's Bureau of Economic Analysis), and other counties which are linked to the Y-W SMSA through journey-to-work commuting patterns and which attract SMSA residents to their retail and service establishments.

Thus, the model utilized in this study is a complex form of the economic basetype approach and includes three major parts (or modules):

(1) Steel Industry Module-consists of three submodules, which are linked together:

- Production process and operating capacity, including capital equipment utilized; input mix of labor, raw materials, and utilities; and the proportions in which all inputs are combined to produce the steel products. This model is developed on a plant-by-plant basis for all participating steel firms which currently have plants located along the banks of the Mahoning River.

- Market and profitability analysis, based upon historic and projected sales and cost data, and the rates-of-return on capital and employment-to-sales ratios of the plants as they existed and are projected to exist in the $a b$ sence of the new standards and implementation schedule.

- Pollution abatement (residuals management) strategy, cost analysis, and impact, including the types of capital equipment required to satisfy the standards on a department-by-department basis (e.g., for coke ovens, blast furnace, hot and cold rolling); the capital outlays and annual operations and maintenance costs associated with these physical requirements (including those generated by increased air pollution and/or solid waste resulting from the adopted strategy); alternatives open to the steel industry with respect to each of the Mahoning Valley plants (as determined by a long-run analysis of profitability on a plant-by-plant basis); and possible effects on employment levels, quantities of materials purchased from suppliers, and quantities of final product available to purchasers as a result of the production decisions made by the industry.

(2) Economic Impact Module-begins with the direct employment and income efferts resulting from the adjustments made by industry, and traces through the multiplier effects resulting both from the supplier/purchaser linkages within the region and from any changes in final consumption, private investment, and government (federal, state, and local) expenditures in the region. This module consists of a modified input/output-type matrix (emphasizing the steel industry) and a (Keynesian) model relating consumer, investor, and government behavior (with respect to initial changes in area income) to the total impact of initial changes on area income and employment. This impact analysis traces the income generation process through a series of steps ovar time, resulting in the projected multiplier effect either being fully realized or affected in mid-stream by some other force coming from outside or inside the regional economy. The module shows the 
degree to which the possible decline of steel industry employment, owing to the implementation of water quality standards, is attributable to the standards (or at least partially to general conditions within the steel industry) and the degree to which the skills of those workers affected adversely are transferable to other jobs either inside or outside of the region.

(3) Fiscal Impact Module - traces the impact of the region's economic adjustments on the revenue of local governments (e.g., from earnings, property, and sales taxes) and expenditures incurred at both local and state levels of government (e.g., increases in unemployment compensation and emergency public works projects and possible declines in provision of municipal services such as trash collection). These net impacts are then fed back into the Economic Impact Module to determine the degree to which the government acts as a stabilizing force in the region's employment and income picture and the degree to which the local units of government may encounter "fiscal crises" in trying to maintain the provision of services to area residents at existing levels.

The model provides WREDA with the analytic basis for reaching a decision regarding the potential economic impact of the water quality standards on the valley. It also allows the tracing of the effects of changes in operating procedures of the major steel producers in the area on all aspects of the regional economy. This, in turn, will assist WREDA and local officials in determining whether the benefits expected from cleaning up the Mahoning River are worth the full costs of its cleaning over the next three years and of maintaining the river at this new standard of cleanliness into the foreseeable future.

\section{STUDY FINDINGS}

\section{Summary of Steel Industry Significance in the Study Area}

Tables 1 and 2 summarize the economic and fiscal significance-both direct and indirect-of the steel industry to the Y-W SMSA in 1972. As is evident from these tables, the steel industry is a significant contributor (direct and indirect) to both the economy and the public sector revenue base of the Y-W SMSA.

Definitions of the three components of significance and the way in which the estimates contained in Tables 1 and 2 were derived can be summarized as follows:

(1) Direct effects: Estimates of jobs, earnings, and local property and earnings-based taxes were derived directly from questionnaires administered to the participating steel companies (the sample covered. 85 percent of jobs in the steel industry included in Bureau of Labor Statistics' reports).

(2) Interindustry effects

(a) Local purchases by steel industry: The dollar value of steel industry purchases from all other producing sectors was secured from our questionnaires (using the format employed in input-output and economic base studies). We asked the respondents to divide their pur- 
TABLE 1

SUMMARY OF ECONOMIC SIGNIFICANCE OF THE STEEL INDUSTRY TO THE Y-W SMSA, 1972

(Based on Ernst \& Ernst sample)

Item

(1) Direct Steel Industry Production

(2) Interindustry Effects

- Local Purchases by

Steel Industry

- Transactions Multiplier

(3) Income Base Multiplier Total

(4) Totals, SMSA (non-agricultural)

(5) Percent of Y-W SMSA totals attributable to Steel

Industry (direct \& indirect) (3 divided by 4 )
Jobs

25,600

271.3

1,737

16.2

1,563

$10,000-26,300$

14.6

$38,900-55,200$

$\$ 75.0-\$ 197.3$

$201,500^{1}$

$\$ 377.1-\$ 499.4$

$\$ 1,952.6^{2}$

$19.3 \%-27.4 \%$

$19.3 \%$

$25.6 \%$

1Source: Bureau of Labor Statistics, 1972 Annual Average.

${ }_{2}^{2}$ Estimated by using 1970 Bureau of Economic Analysis earnings data and inflating it by a five percent per annum compounded growth rate to derive an estimate for 1972.

TABLE 2

SUMMARY OF FISCAL SIGNIFICANCE ${ }^{1}$ OF THE STEEL INDUSTRY TO THE Y-W SMSA, 1972 (Based on Ernst \& Ernst sample)

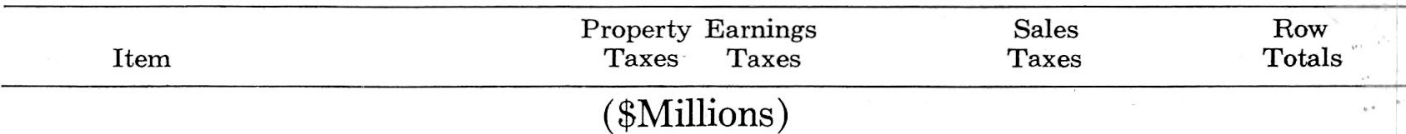

(1) Direct Steel

\begin{tabular}{|c|c|c|c|c|c|c|}
\hline Industry Production & $\$ 11.2$ & $\$ 3.3$ & $\$ 3.3-\$$ & 8.0 & $\$ 17.8-\$$ & $\$ 22.5$ \\
\hline dustry Effects & 2 & 0.3 & $9.3-$ & 9.8 & $9.6-$ & 10.1 \\
\hline Base Multiplier & 2 & $0.8-\$ 5.6$ & $1.0-$ & 5.0 & $1.8-$ & 7.0 \\
\hline Total & $\$ 11.2$ & $\$ 4.4-\$ 5.6$ & & & & \\
\hline
\end{tabular}

(4) Total Revenues, all SMSA political jurisdictions

(Including those derived from excise taxes) ${ }^{3}$

$\$ 142.1$ Million

(5) Percentage of total revenues attributable to

Steel Industry (3 divided by 4 )

$20.5 \%-27.8 \%$

\footnotetext{
1 Excise taxes not estimated.

2 Not estimated.

3Total revenues for 1972 are estimated from the 1967 Census of Governments figure for Mahoning and Trumbull counties ( $\$ 117.0$ million), inflated by a five-percent per annum compounded growth rate to establish a 1971-72 fiscal year estimate.
} 
chases (recorded in producers' prices) into two categories: "local" (from plants located within the two-county SMSA) and "non-local" (all others). The sales figures were then translated into "job" and "annual wage and salary equivalents" using a variety of sources. ${ }^{6}$ The purchases data were combined with figures on local sales by the steel companies (secured from the same questionnaire) to estimate local sales taxes generated by these transactions.

(b) Transaction multiplier: The transactions multiplier is used to estimate the additional jobs and earnings (as well as taxes) induced by the steel industry. For example, the steel industry purchased over $\$ 12$ million of industrial machinery from local plants in 1972. In order to produce this $\$ 12$ million worth of machinery, these plants employed certain amounts of labor and capital but also purchased additional materials from other local producers, resulting in still more jobs and earnings. Rough estimates of the total significance of these multiplier effects were made by using the sector-by-sector value added multipliers estimated in the 1966 National Input-Output Study ${ }^{\top}$ and making certain assumptions regarding their applicability to the Youngstown area economic base. The same basis was used for dividing these effects between local and non-local, and a concerted effort was made to avoid double-counting.

(3) Income base multiplier: The final type of indirect effect is that attributable to the economic base income (or value added) multiplier resulting from the annual income attributable to the steel industry in the Youngstown area (the totals derived from items $1,2 \mathrm{a}$, and $2 \mathrm{~b}$ above). Allowing for leakages to taxes, personal savings, and consumption expenditures on goods and services sold and/or produced non-locally, an income multiplier ranging between 1.25 and 1.67 was estimated. ${ }^{\mathrm{s}}$ Time-series analysis relating changes in basic to non-basic employment and earnings was the main technique used to arrive at the upper limit of 1.67 . The lower limit of 1.25 was derived by making very conservative estimates regarding how many additional jobs and how much income could really be attributed to the presence of the steel industry in the SMSA.

\section{The Costs of Meeting the Standards}

In order to meet the Ohio State Water Quality Standards, capital outlays of roughly $\$ 140$ million reportedly will have to be made by the steel industry over a 31/2-year period (mid-1973 to December 1976) - about $\$ 40$ million per year. ${ }^{2}$ In addition, these investments will lead to the incurrence of an estimated additional $\$ 20$ million to $\$ 25$ million of operating and maintenance costs per year (including depreciation expenses, a tax deductible item) once the capital equipment is in place. The above figures do not include additional air pollution and solid waste investment and annual operating costs that will have to be incurred once the Federal and Ohio Environmental Protection Agencies establish clean-up provisions (including schedules) in the latter two areas. The costs of complying with the Occupational Health and Safety Act are likewise excluded from the above estimates. 
A key item concerns the identification of the types and quantities [expressed as concentrations (parts of pollutant per million parts of water of "ppm") and/or loads (pounds of pollutant discharged per day)] of all pollutants currently being discharged into the Mahoning River by each production (or productionrelated) department under normal operating conditions. ${ }^{10}$ The data reveals that of 145 pollutant (including thermal) discharge-department operation combinations reported (e.g., oil-blast furnace), 90 pollutant concentrations, loads, or out-fall temperatures exceed the allowable standards adopted by the Ohio Water Pollution Control Board; 38 of the concentrations, loads or out-fall temperatures are within the allowable tolerances; and the acceptability of the remaining 17 cannot be judged because of the inability of the companies to determine the allowable standards (i.e., none of the four companies was able to interpret the standards for these discharges). This last case includes pollutants such as chlorides, sulphates, aluminum, manganese, and nickel.

A review of the magnitude by which the 90 currently excessive pollutant discharges exceed the allowable standards showed that many discharges are not currently far beyond tolerable limits. However, some of the discharges greatly exceed the allowable standards. The enormity of the water clean-up problem facing the companies can be seen by the following listing of examples of pollutants discharged by certain operations, selected randomly throughout the four companies, and the degree by which the listed pollutant exceeds the allowable standard:

\section{Pollutant Discharged \\ Ammonia \\ Dissolved iron \\ Zinc \\ Cyanide \\ Phenols}

Suspended solids

Oil

Thermal

\section{Ratio of Current Discharge to}

Allowable Standard

30 times allowable concentration

100 times allowable concentration

57 times allowable concentration

600 times allowable concentration

60 times allowable concentration

14 times allowable concentration

17 times allowable concentration

3 times allowable temperature increase

While many of the projected capital expenditures were allocated to individual production departments and operations, a number were allocated to groups of operations and, in several cases, to the entire plant. Thus, it is not entirely clear, for example, which type of operation would be the most costly to clean up. It appears reasonably accurate from the cost data, however, to state that the water pollution resulting from primary or "steelmaking" operations (i.e., coking, sintering, blast furnaces, and steel melting) as well as the "hot forming" processes-billet, blooming, and slabbing mill operations-will be approximately twice as costly to correct as that of finishing or "downstream" operations. The latter includes operations such as hot strip mills, hot rolling mills, cold strip and cold rolling mills, pickling, pipe-producing mills, and galvanizing and annealing operations. Additionally, though again we emphasize that the projected costs cannot be allocated to specific departments (or "cost centers") in their entirety, the in- 
dividual department/operations requiring the largest water pollution abatement expenditures appear to be, in order of greatest costs:

(1) Blast furnaces

(2) Coke plants

(3) "Hot forming" operations (blooming, billet, and slabbing mills). The projected investment expenditures for abating water pollution in these three types of operations alone amount to $\$ 70$ million.

The allocation of the above capital outlays by type of discharge to be cleaned up is also of interest. The data indicates that total capital costs required throughout the four companies for dissolved solids removal — by a process alternately called "ion exchange" or "demineralization"-represent the largest type of expenditure projected. Expenditures on facilities to be used for filtration of suspended solids and, to some extent, oil, from processing water are projected to be second highest. The costs estimated for reduction of thermal (heat) pollution, using such techniques as cooling towers and recirculation of process and cooling water, rank third. Finally, expenditures projected for clarification, skimming, flocculation and vacuum filtering of oil from process water rank fourth. Other types of water pollution abatement measures expected to be used by the companies include:

- Biological treatment of phenols and cyanide

- Neutralization of acids

- Chlorine oxidation of cyanide

- Sulphur dioxide reduction of chromium

- Installation of additional flue dust thickeners.

\section{CONCLUSIONS}

The compliance schedule contained in the Ohio State Water Quality Standards will force the management of the steel companies to make final decisions in the near future regarding the economic viability of their eight mills located in the Mahoning Valley. The benefits of cleaning up/refurbishing (and possibly expanding production capability concurrently) must be weighed against the costs. The real question is whether the companies will choose to retain the Mahoning Valley as a continuing center of steel production or shift their production facilities to other geographic areas. The arguments can be summarized as follows:

a. Positive

- Strong demand for all types of steel products through the 1970's, leading to a premium being placed on existing productive capability

- Skilled labor pool in place

- Established linkages both with suppliers and purchasers

- Elaborate network of interstate highways and railroads providing direct linkages to markets through Ohio, West Virignia, and Kentucky

b. Negative

- High cost of clean-up (particularly the coke ovens, blast furnaces, and hot forming operations) and risk that additional investments may still be needed to meet the 1983 legislative goals of Congress 
- Shifting of markets for products to the Southwest and West and the sources of raw materials to foreign countries, making the Y-W area a less favorable one for locating fully-integrated steel mills because of high transportation costs

- Recent trends in the industry toward building "mini-mills" (using electric arc furnaces), which produce the specialty products yielding (currently) greater profit margins, use steel scrap as input, and do not present the pollution problems of the Basic Oxygen Furnaces (BOFs) they are also less labor intensive than the traditional, fully integrated mills, which could further stimulate the secular decline in employment in the steel industry as even greater productivity increases are attained

- Financial condition of the industry, which is plagued with high debtto-equity ratios, a low rate of return on present investments, and cash flow problems.

The steel industry has three alternatives which illustrate the courses of action that the four major companies are likely to take. These are:

- Alternative One. Undertake all necessary pollution abatement investments and maintain operations as is into the foreseeable future.

- Alternative Two. Complete shutdown of all plants which either contain ar open-hearth furnace or whose finishing operations rely on raw steel produced in open-hearth furnaces.

- Alternative Three. Selective shutdown/consolidation of overlapping primary operations by individual companies to reduce the amount of capital required to meet the water quality standards; total productive capability would be reduced with ramifications for finishing operations.

The economic and fiscal impacts of alternatives two and three are summarized in the following table:

\begin{tabular}{|c|c|c|c|}
\hline & $\begin{array}{c}\text { Jobs } \\
\text { (number) }\end{array}$ & $\begin{array}{l}\text { Loss of: } \\
\text { Earnings } \\
\text { (\$millions) }\end{array}$ & $\begin{array}{l}\text { Taxes* } \\
\text { (\$millions) }\end{array}$ \\
\hline & & Direct Impact & \\
\hline \multirow{3}{*}{$\begin{array}{l}\text { Alternative Two } \\
\text { Alternative Three }\end{array}$} & 15,400 & $\$ 151.8$ & $\$ 8.8-\$ 1$ \\
\hline & $6,000-7,500$ & $65.0-81.0$ & $3.2-$ \\
\hline & \multicolumn{3}{|c|}{ Indirect (Multiplier) Impact } \\
\hline \multirow{3}{*}{$\begin{array}{l}\text { Alternative Two } \\
\text { Alternative Three }\end{array}$} & $6,225-13,490$ & $\$ 50.1-\$ 104.6$ & $\$ 6.9-\$$ \\
\hline & $2,425-6,570$ & $19.5-\quad 50.9$ & $2.5-$ \\
\hline & \multicolumn{3}{|c|}{ Totals (Direct plus Indirect) } \\
\hline Alternative Two & $21,625-28,890$ & $\$ 201.9-\$ 256.4$ & $\$ 15.7-\$ 2$ \\
\hline Alternative Three & $8,425-14,070$ & 81.0- 127.9 & $5.7-$ \\
\hline
\end{tabular}




\section{FOOTNOTES}

1State of Ohio Department of Health, Water Pollution Control Board, "Water Quality Standards Adopted by the Board," July 11, 1972, for the Mahoning River Valley and its Tributaries in Ohio, 1972.

2Using Bureau of Labor Statistics data for March 1973, the SMSA's location quotient for Sector 331 ("blast furnace-steel") was 18.0; it was 13.3 for Sector 33 ("primary metals").

${ }^{3}$ The following studies were utilized in securing the above information: Booz-Allen Public Administration Services, Inc., A Study of the Economic Impact on the Steel Industry of the Costs of Meeting Federal Air and Water Pollution Abatement Requirements, prepared for the Council on Environmental Quality (Washington, D.C.: National Technical Information Service, 1971, PB-211-917, 918, 919, 3 vols.); Alan T. Demaree, "Steel: Recasting an Industry," Fortune Magazine, March 1971, pp. 74-77, 134-42; William T. Hogan, S. J., The 1970s: Critical Years for Steel (Lexington, Mass.: D. C. Heath and Co. 1972).

4 In 1974, the steel industry employed approximately 30,500 people, accounting for 32.7 percent of manufacturing employment and 14.1 percent of total non-agricultural employment in the Y-W SMSA.

5 Described most succinctly by Charles M. Tiebout, The Community Ecoonmic Base Study (New York: Committee for Ecoonmic Development, Supplemental Paper \#16, December 1962). See also W. Lee Hansen and Charles M. Tiebout, "An Intersectoral Flows Analysis of the California Economy," Review of Economics and Statistics, Vol. XLV, No. 4, Nov. 1963, pp. 409-418. An earlier application of various regional economic techniques to the Youngstown area is by City Planning Associates, Inc., Regional Economic Study: A Program for Community Renewal Youngstown and Mahoning County, Nov. 1968 (mimeo).

6Specifically, Ohio State Bureau of Employment Services, Ohio Labor Market Information. Youngstown-Warren Metropolitan Area (Monthly: Jan. 1961-March 1973); Walter Isard, et al., Philadelphia Region Input-Output Study (Philadelphia: University of Pennsylvania, 1966-68, 4 vols.); U.S. Bureau of the Census, Census of Business (Wholesale Trade, Retail Trade, and Selected Services) and Census of Manufactures, 1967, State Reports: Ohio (any dollar figures used from these reports were inflated to 1972 levels).

${ }^{7}$ U.S. Department of Commerce, Bureau of Economic Analysis, Input-Output Transactions-1966(Washington, D.C.: National Technical Information Service, COM 72-10299, 1972) and its predecessor study, Input-Output Structure of the U.S. Economy: 1963 (A Supplement to the Survey of Current Business, 3 vols.).

8This range is consistent with that postulated by Charles M. Tiebout, The Community Economic Base Study, op. cit.

9The source of all information regarding compliance costs is taken from detailed questionnaires completed by the participating companies.

10 Heat, or thermal pollution, is also identified in terms of the temperature (in degrees Fahrenheit) of the river's water at various "mixing zones" and its deviation from "desired" levels. 